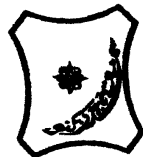

Bayero Journal of Pure and Applied Sciences, 5(1): 127 - 131

Received: December, 2011

Accepted: March 2012

ISSN $2006-6996$

\title{
EVALUATION OF MICROBIOLOGICAL SAFETY OF HERBAL CONCOCTIONS SOLD IN SOME MARKETS IN GABASAWA AND NASSARAWA LOCAL GOVERNMENT AREAS IN KANO STATE
}

Ebo, P. U., Mukhtar, M.D. and Taura, D.W.

Department of biological sciences, Bayero University Kano State, Nigeria.

\begin{abstract}
A study was carried out on the microbial safety of herbs sourced from some markets in Gabasawa Local Government and Nassarawa Local Government Areas in Kano state. A total of 12 different sample of herbal concoctions were collected from vendors in 2 market from the two Local Government Areas. Enumeration of coliform count, and aerobic bacterial count were carried out using MPN (Most Probable Number) and pour-plate techniques respectively. Enumeration of fungi was also carried out using pour-plate technique. Specific pathogens were also isolated and characterized using standard procedures. The result showed that coliform counts ranged between $<3$ and >2, 4000 MPN/ML. the mean aerobic viable bacterial count/m/ ranged between $<3 \times 10^{2}$ $\mathrm{cfu} / \mathrm{ml}$ and TNC (too numerous to count) $\mathrm{cfu} / \mathrm{ml}$, while that of fungal counts ranged from $<1 \times 10^{1}$ to TNC cfu/ml. the occurrence of Escherichia coli is $58.33 \%$, yeast $(75 \%)$, Aspergillus spps. (41.67\%). Penicillium spps. (16.67\%), Mucor spps. (33.33\%), Rhizopus spps. (41.67\%). The findings showed a high microbial contamination among the varieties of concoctions sampled. Adoption of hygiene and good manufacturing practices are therefore recommended as they can improve safety and acceptability of herbal preparations.

Keywords: Concoctions, Safety, Kano, Herbal, Market
\end{abstract}

\section{INTRODUCTION}

Ever since the dawn of human civilization, humans have been adding value to biodiversity through innumerable ways and means. The third world countries are rich in biodiversity and also have a strong cultural history (Sri Lanka Ayurvedit drug cooperation (SLADC 1969). The people living in different agro-climatic conditions in these countries have developed a knowledge system known as Traditional Knowledge (TK) about the use of resources found around them by trial, error, experimentation and incremental refinement as well as by empirical reasoning (SLADC 1969).

By definition, a herb is a plant or part of a plant valued for its medicinal, aromatic or savoury qualities. Herbal medicine or herbalism is the use of herbs or herbal products for their therapeutic or medicinal value (SLADC 1969). There are a vast number of plants used by the Hausas to treat urinary tract infections, some of which include Cassia occidentalis or "Raidore" (in Hausa) Psidium guajava or "Goba" (in Hausa), Ocimum gratissimum or "Doddoya" (in Hausa), Ricinus communis or "Zurman" (in Hausa), Moringa Oleifera or "Zogale" (in Hausa) Indigofera astragalina or "Kaikayi koma kan mashekiya" (in Hausa), Hibiscus sabdariffa or "Zoborado" (in Hausa), Croton zambesicus or "Goriba" (in Hausa), Combretum leestingii or "Dagera" (in Hausa), and Peristrophe bicalyculata or "Hayyadaga" in Hausa. (Junju, 1990, Shariff 2001).

In this study, investigation was carried out on the bacterial and fungal safety of herbal concoctions prepared locally for the treat of various illness (Table 1). The twelve herbal concoctions were obtained from vendors in two markets each, from Gabasawa and Nasarawa Local Governments Areas in
Kano State. Tremendous efforts had been made by NAFDAC to ensuring good quality of herbal preparations in Nigeria. However, this body had been faced with a lot of constraints (Ugwunebo 2002).

\section{MATERIALS AND METHODS}

\section{Sampling site}

The sampling sites were two markets one each from Gabasawa and Nassarawa Local Government Areas, namely; Zakirai market and Yankaba Market respectively. The sites were chosen because, they serve as outlets of various concoctions to the consumers. A general survey of the two markets was conducted to identify the different herbal concoctions available on sale (table 1). Samples were collected on market day basis during afternoons.

\section{Sample collection}

The temperature of the concoctions were recorded at the time of sampling. All sample containers were labeled immediately before the samples were taken following the FAO (1979) protocols.

\section{Physicochemical parameters}

Temperature

A liquid -in-glass thermometer was used which was put in contact with the concoction and the temperature recorded (Electronic Code of Federal Regulations-ECFR, 2008).

pH

A digital $\mathrm{pH}$ metre, model Jenway 3305 was used to determine the $\mathrm{PH}$ of the samples.

Turbidity

The turbidities of the samples were determined using Hach DR/2010 spectrophotometre. 


\section{Colour}

The colours of the concoctions were assessed and recorded.

\section{Enumeration of viable aerobic mesophilic} bacteria

The enumeration of viable aerobic mesophilic bacteria was carried out following the FAO 1979 protocol.

\section{Enumeration of coliform bacteria using MPN technique}

The enumeration of caliform bacteria was also carried out following the FAO 1979 protocol.

Biochemical characterization of medically important isolates: Detection of Escherichia coli:

This was carried out according to the procedures specified by the Food and Agricultural Organization (1979).

\section{Enumeration of yeasts and moulds}

This was carried out according to the procedures specified by FAO 1979.

\section{RESULTS}

The names, compositions, indications and route of administration of different types of concoctions are shown in Table 1.

The physicochemical features are shown in table 2. The $\mathrm{PH}$ of the samples ranged between 4.70 and 7.80, while the temperature ranged between $29.00^{\circ} \mathrm{C}$ and $37.00^{\circ} \mathrm{C}$. none of the samples have neither batch number nor NAFDAC number in terms of packaging, 5 (five) of the samples $(33.33 \%)$ were packaged in used transparent plastic container, another $4(41.67 \%)$ were packaged in brown breakable bottles, $1(8.33 \%)$ was packaged in transparent breakable bottle, the other $1(8.33 \%)$ was packaged in leather bag, while the remaining $8.33 \%$ was packaged in transparent breakable bottle, the other $1(8.33 \%)$ was packaged in water-proof leathe$r$, while the remaining $8.33 \%$ was packaged in white plastic rubber. The turbidity of the various samples ranged between $151 \mathrm{FAu}$ to $14436 \mathrm{FAU}$. In terms of collour, the samples had various colours such as brown, reddish-brown, dirty green, yellow yellowish brown.

The most probable number (MPN) counts for coliform, mean aerobic bacterial counts, mean fungal counts, and their safe levels are shown in table 3 . The $\mathrm{MPN} / \mathrm{ml}$ of the samples ranged from $<3$ to $>2,400$ per $\mathrm{ml}$. The mean aerobic viable bacterial count $/ \mathrm{ml}$ ranged between $<3 \times 10^{2} \mathrm{cfu} / \mathrm{ml}$ and TNC. Based on standards of food and Agricultural Organization, 50\% of the total samples appeared safe at $95 \%$ confidence limit, while the remaining $50 \%$ were found to be unsafe for human consumption as drugs. According to European pharmacopoeia (2007), the safe level for non-sterile herbal preparation is $10^{7}$ bacteria per $\mathrm{ml}$. This by implication, shows that $50 \%$ of the sample were safe, while the other $50 \%$ were unsafe. Also according to European pharmacopoeia (2007), the safe level for fungal count is $10^{5}$ fungi per $\mathrm{ml}$. This indicates that $50 \%$ of the total samples appeared safe, while the remaining $50 \%$ were found to be unsafe.

Table 4 shows the different bacteria and fungi defected in various samples. $E$. coli (plate 1) was detected in (58.33\%) of the samples, Aspergillus spps.(plate 2) (53.33\%), penicillium spps. (plate 3) $(16.67 \%)$ other include, mucor spps. (33.33\%), Rhizopus spps. (41.67\%), yeast (75.0\%). Salmonella spps., Clostridium perfringens, Bacillus cereus were not detected in any of the samples.

\section{DISCUSSION AND CONCLUSION}

The study confirmed a preponderance of orally consumed herbal medications in Gabasawa and Nassarawa Local Government Areas. The samples were all water-based. In addition, majority of the samples appeared not to have been produced by following good manufacturing practices. The questions on the use of safety codes, as well as NAFDAC regulations were yet not answered. This was given by the lack of any trace of pharmacopoeial details excepting brand names in few of the products. That, also accounted for the high recovery rate of coliforms and other fungal contaminants that rendered the products virtually fearful. The high recovery rates of these suspected hazardous microorganisms from indigenous orally consumed herbal medication is therefore of great clinical importance.

The samples were found to be not safe because, the present investigation identified high microbial load. Most of the bacterial isolates were coliforms including $E$. coli while the fungi isolated include Aspergillus spps., Yeast, Penicillium spps., Mucor spps., and Rhizopus spps. In terms of Coliform count, it was found according to FAO 1979 at 95\% confidence limit, that $6(50 \%)$ of the total samples were within the acceptable limit, while the other $50 \%$ were found not within the acceptable limit (table 2). The presence of coliforms indicated faecal pollution, which indeed, may indicate a possible presence of harmful, disease-causing organisms (APHA 1992).

The presence of bacterial contaminants in the herbal concoctions is related to the source or poor quality of water used for the processing. Additional sources of contamination might be from the packaging materials which are not usually or poorly sterilized. The coliform associated with the sold herb concoctions created suspicion not only on the water used during preparation, but the handlers as well as the raw plant material during collection, drying, processing and dispensing. This may mean exposing consumers to dangers of gastroenteritis (Mukhtar et al, 2001). 
Bajopas Volume 5 Number 1 June, 2012

Table 1: Names, compositions, indications and route of administration of different types of concoctions sold in zakirai and yakaba market

\begin{tabular}{|c|c|c|c|c|c|}
\hline $\mathbf{S} / \mathbf{n}$ & Sample & Names & Composition & Indication & $\begin{array}{l}\text { Route of } \\
\text { Administration }\end{array}$ \\
\hline 1 & ZK1 & Maganin tari & $\begin{array}{l}\text { Marke (erect ork), } \\
\text { tafarnuwa (garlic), } \\
\text { citta (Ginger) zuma } \\
\text { (honey) }\end{array}$ & Cough & Oral \\
\hline 2 & ZK2 & $\begin{array}{l}\text { Maganin basir } \\
\text { (haemorrhoid) }\end{array}$ & $\begin{array}{lr}\text { Ararrabi, } & \text { farar } \\
\text { dorawa, mangwaro, } \\
\text { danya, kirya, jar } \\
\text { kanna }\end{array}$ & Pile, dysentery & Oral \\
\hline 3 & ZK3 & $\begin{array}{l}\text { Maganin Ruga- } \\
\text { Kafi (prevention) }\end{array}$ & $\begin{array}{l}\text { Marki, (erect ork) } \\
\text { farar albasa, white } \\
\text { onions tafarnuwa } \\
\text { (garlic) hulba }\end{array}$ & Antibiotic & Oral \\
\hline 4 & ZK4 & $\begin{array}{l}\text { Maganin } \\
\text { zazzabin } \\
\text { shawara (yellow } \\
\text { fever) }\end{array}$ & NR & Yellow fever & Oral \\
\hline 5 & ZK5 & $\begin{array}{l}\text { Maganin fuka } \\
\text { (asthma) }\end{array}$ & NR & Stomach problems, asthma & Oral \\
\hline 6 & ZK6 & $\begin{array}{l}\text { Maganin zazzabi } \\
\text { cizon sauro } \\
\text { (malaria) }\end{array}$ & NR & Anti-malaria, yellow fever & Oral \\
\hline 7 & YK1 & $\begin{array}{l}\text { mai tafar nuwa } \\
\text { (Garlic seed oil) }\end{array}$ & $\begin{array}{l}\text { Pure and natural } \\
\text { garlic seed oil }\end{array}$ & $\begin{array}{l}\text { Artery expansion, blood pressure, } \\
\text { cholesterol control, skin disease, anti- } \\
\text { malaria }\end{array}$ & Oral \\
\hline 8 & YK2 & Black seed oil & Black seed oil & Stomach problem, skin problems & Oral \\
\hline 9 & YK3 & & NR & Stomach problem & Oral \\
\hline 10 & YK4 & $\begin{array}{l}\text { Maganin Haila } \\
\text { (menses) }\end{array}$ & NR & $\begin{array}{l}\text { Regulates menses, clears odour from } \\
\text { private parts }\end{array}$ & Oral \\
\hline 11 & YK5 & $\begin{array}{l}\text { Maganin fuka } \\
\text { (asthma) }\end{array}$ & NR & Asthma & Oral \\
\hline 12 & YK6 & Maganin jadijadi & NR & Gadigadi & Oral \\
\hline
\end{tabular}

Keys:- ZK = Zakirai, ZKI - samp 1, ZK 2=sample 2, ZK3 = Sample 3, ZK4 = Sample 4, ZK5 = keys Sample 5, ZK6 = Sample 6. YK=Yankaba, YK1=Sample 1, YK $2=$ Sample 2, YK $3=$ Sample 3, YK $4=$ Sample 4, YK5 = Sample 5, YK 6= Sample 6, FAU= formazin Attenuation units, Nil = no information.

Table 2: The physicochemical features of herbal concoctions sold in Zakirai and Yankaba Markets in Kano StateNo.

\begin{tabular}{|c|c|c|c|c|c|c|c|c|}
\hline $\mathbf{S} / \mathbf{N}$ & Sample & PH & Temp $\left({ }^{\circ} \mathrm{C}\right)$ & Turbidity & Colour & $\begin{array}{l}\text { Batch } \\
\text { No. }\end{array}$ & $\begin{array}{l}\text { NAFDAC } \\
\text { No. }\end{array}$ & Package \\
\hline 1 & ZK I & 5.45 & 37.0 & 2120FAU & Brown & Nil & Nil & Plastic transparent \\
\hline 2 & ZK II & 5.31 & 37.0 & 2035FAU & Reddish brown & Nil & Nil & Plastic transparent \\
\hline 3 & ZK III & 5.55 & 31.0 & 2180FAU & Dirty green & Nil & Nil & Plastic transparent \\
\hline 4 & ZK IV & 6.15 & 31.0 & 2508FAU & Reddish brown & Nil & Nil & Plastic transparent \\
\hline 5 & ZK V & 7.80 & 29.0 & 154FAU & Reddish brown & Nil & Nil & Plastic transparent \\
\hline 6 & ZK VI & 7.40 & 30.0 & 14436FAU & Brown & Nil & Nil & White plastic \\
\hline 7 & YK I & 4.70 & 30.6 & 474FAU & Yellow & Nil & Nil & Brown bottle \\
\hline 8 & YK II & 5.60 & 30.6 & 151FAU & Yellowish brown & Nil & Nil & Brown bottle \\
\hline 9 & YK III & 5.70 & 30.7 & 2075FAU & Reddish brown & Nil & Nil & Brown bottle \\
\hline 10 & YK IV & 5.37 & 29.7 & 2231FAU & Reddish brown & Nil & Nil & Brown bottle \\
\hline 11 & YK V & 6.50 & 29.6 & 261FAU & Reddish brown & Nil & Nil & Transparent bottle \\
\hline 12 & YK VI & 6.40 & 29.5 & 277FAU & Brown & Nil & Nil & Leather bag \\
\hline
\end{tabular}

Keys: Zk=Zakirai, $\mathrm{ZK}_{1}=$ Sample 1, $\mathrm{ZK}_{2}=$ Sample 2, $\mathrm{ZK}_{3}=$ Sample 3, ZK $\mathrm{K}_{4}=$ Sample 4, $\mathrm{ZK}_{5}=$ Sample $5, \mathrm{ZK}_{2}=$ sample 6. $\mathrm{YK}=$ Yankaba, $\mathrm{YK}_{1}=$ Sample $1, \mathrm{YK}_{2}=$ Sample 2, $\mathrm{YK}_{3}=$ sample 3, $\mathrm{YK}_{4}=$ Sample 4, $\mathrm{YK}_{5}=$ Sample 5, $\mathrm{YK}_{6}=$ $=$ Sample 6. TNC $=$ too numerous to count. 
Table 3: Microbial counts in different herb concoctions sold in Zakirai and Yakaba Market Kano state

\begin{tabular}{|c|c|c|c|c|c|c|c|c|c|c|}
\hline $\mathbf{S / N}$ & Sample & $\begin{array}{l}\text { MPN/ml } \\
\text { (for } \\
\text { coliform) }\end{array}$ & $\begin{array}{l}95 \% \\
\text { Confidence } \\
\text { Limit }\end{array}$ & & $\begin{array}{l}\text { Remarks } \\
\text { (for } \\
\text { MPN) }\end{array}$ & $\begin{array}{l}\text { Mean } \\
\text { aerobic } \\
\text { count }\end{array}$ & $\begin{array}{l}\text { safe } \\
\text { level } \\
10^{7}\end{array}$ & $\begin{array}{l}\text { Mean } \\
\text { anaerobic } \\
\text { Count }\end{array}$ & $\begin{array}{l}\text { Fungal } \\
\text { Count }\end{array}$ & $\begin{array}{l}\text { Safe } \\
\text { level } \\
10^{5}\end{array}$ \\
\hline & & & Lower upper & & & & & & & \\
\hline 1 & ZK I & $>2,400$ & & & Unsafe & TNC & Unsafe & $2.2 \times 10^{4}$ & TNC & unsafe \\
\hline 2 & ZK II & $>2,400$ & & & Unsafe & TNC & Unsafe & $1.1 \times 10^{4}$ & TNC & unsafe \\
\hline$\overline{3}$ & ZK III & $>2,400$ & & & Unsafe & TNC & Unsafe & TNC & TNC & unsafe \\
\hline 4 & ZK IV & $>2,400$ & & & Unsafe & TNC & Unsafe & TNC & TNC & unsafe \\
\hline 5 & ZK V & $>2,400$ & & & Unsafe & TNC & Unsafe & TNC & TNC & unsafe \\
\hline 6 & ZK VI & $>2,400$ & & & Unsafe & $<3 \times 10^{2}$ & Safe & $<3 \times 10^{2}$ & TNC & unsafe \\
\hline 7 & YK I & $<3$ & & & Safe & $<3 \times 10^{2}$ & Safe & $3.0 \times 10^{3}$ & $8.5 \times 0^{2}$ & safe \\
\hline 8 & YK II & $<3$ & & & Safe & $<3 \times 10^{2}$ & Safe & $<1 \times 10^{1}$ & $2.6 \times 0^{3}$ & safe \\
\hline 9 & YK III & $<3$ & & & Safe & $<3 \times 10^{2}$ & Safe & $1.2 \times 10^{3}$ & $2.3 \times 10^{3}$ & safe \\
\hline 10 & YK IV & II & 3 & 36 & Safe & TNC & Unsafe & $1.4 \times 10^{4}$ & $1.4 \times 10^{4}$ & safe \\
\hline 11 & YK V & II & 3 & 36 & Safe & $5.1 \times 10^{3}$ & Safe & $5.4 \times 10^{3}$ & $5.2 \times 10^{3}$ & safe \\
\hline 12 & YK VI & $<3$ & & & Safe & $3.3 \times 10^{3}$ & Safe & $3.4 \times 10^{3}$ & $<3 \times 10^{2}$ & safe \\
\hline
\end{tabular}

Key:- Zk = Zakirai, ZK1 = Sample 1, ZK2 = Sample 2, ZK 3 = Sample 3, ZK4 = Sample 4, ZK5 = Sample 5. $\mathrm{YK}=$ Yankaba, $\mathrm{YK}_{1}=$ Sample 1, $\mathrm{YK}_{2}=$ Sample 2, $\mathrm{YK}_{3}=$ sample 3, $\mathrm{YK}_{4}=$ Sample 4, $\mathrm{YK}_{5}=$ Sample 5, $\mathrm{YK}_{6}==$ Sample 6.

Table4: The Pathogenic bacterial and fungal contaminants in the herbal medicinal samples

\begin{tabular}{|c|c|c|c|c|c|c|c|c|c|c|}
\hline $\mathbf{S} / \mathbf{N}$ & Sample & $E C$ & Sal & $C P$ & $B C$ & Yeast & $\begin{array}{l}\text { Aspergillus } \\
\text { spps. }\end{array}$ & $\begin{array}{l}\text { Penicillium } \\
\text { spps. }\end{array}$ & $\begin{array}{l}\text { Mucor } \\
\text { spps. }\end{array}$ & $\begin{array}{l}\text { Rhizopus } \\
\text { spps. }\end{array}$ \\
\hline 1 & ZK 1 & + & - & - & - & + & + & - & - & + \\
\hline 2 & ZK 2 & + & - & - & - & + & + & - & - & + \\
\hline 3 & ZK 3 & + & - & - & - & + & + & - & - & - \\
\hline 4 & ZK 4 & + & - & - & - & + & + & - & + & - \\
\hline 5 & ZK 5 & + & - & - & - & - & + & + & - & - \\
\hline 6 & ZK 6 & + & - & - & - & + & + & - & - & - \\
\hline 7 & YK 1 & - & - & - & - & + & + & - & - & + \\
\hline 8 & YK 2 & - & - & - & - & + & + & - & + & - \\
\hline 9 & YK 3 & - & - & - & - & + & + & - & + & - \\
\hline 10 & YK 4 & + & - & - & - & - & - & - & - & + \\
\hline 11 & YK 5 & - & - & - & - & + & + & - & + & - \\
\hline 12 & YK 6 & - & - & - & - & - & - & + & - & + \\
\hline
\end{tabular}

Keys: ZK = Zakirai, ZK1 = sample 1, ZK $2=$ sample 2, ZK3 = sample 3, ZK4 = sample 4, ZK5 = sample 5, ZK6 = sample 6. Nil $=$ no information, $\mathrm{YK}=$ Yankaba; YK1 $=$ sample, YK2 $=$ sample 2, YK $3=$ sample 3, YK $=$ sample 4, YK5 $=$ sample 5 , YK6 $=$ sample 6- = not present, $+=$ present, $\mathrm{EC}=$ Escherichia coli, Sal = Salmonella $\mathrm{sp}, \mathrm{CP}=$ Clostridium perfringenes, $\mathrm{BC}=$ Bacillus cereus

According to European Pharmacopoeia (2007), the safe level for non-sterile oral herbal preparations is $10^{7}$ bacteria per $\mathrm{ml}$. This, by implication suggests that $50 \%$ of the total samples were within the acceptable limit, while $50 \%$ were found unsafe (Table 3). Also according to European Pharmacopoeia (2007), the safe level for fungal count is $10^{5}$ fungi per $\mathrm{ml}$. This also implies that $50 \%$ of the samples were within the safe level while $50 \%$ were unsafe.

The presence of yeasts, Aspergillus spps, Rhizopus spps., Mucor spps. and Penicillium spps. were not surprising as they are mycoflora and common spoilage organisms of carbohydrate containing foods (Shamsuddeen et al; 2008). The National Agency for Food and Drug Administration and Control (NAFDAC), have been making tremendous efforts in ensuring quality, safety, registration, advertisement and claims on herbal medicines. Upon these efforts, all the samples worked on, had no expiry dates, no batch number, no NAFDAC number (Table 2).
This could suggest that NAFDAC has no control over marketed concoctions in Gabasawa and Nassaraw Local Government Areas probably because of inadequate man-power provision or that policy and laws are not yet promulgated as to handle such products. Presence of contaminating and spoilage organisms and their high count calls for further researches in this areas so as to provide means of encouraging a safer and high quality production of herbal medicaments.

\section{CONCLUSION}

As at the time of this investigation, herbal concoctions sold in Gabasawa and Nassaraw Local Government Areas were microbiologically contaminated, hence, many of the samples could not be recommended for human consumption as drugs. Sequel to this, adequate quality control measures and distribution practices should be adopted. This would reduce the microbial density of the concoctions and so improve their safety and aesthetic values pharmacopoeially. 


\section{REFERENCES}

APHA (1992); In Adenike A.O Oyushe, Taiye R. Faola, A. Egunyomi (2006); Bacterial Profiles and Consumer Preference of some indigenous orally consumed herbal medications in Nigeria Journal of Rural and Tropical Public Health 5:27-33.

Akerele O. (1984); World Health Organisation traditional medicine program, progress and perspective; WHO Chronicle 38: $78-81$.

European Pharmacopoeia (2007); Microbiological quality of Pharmaceutical Preparation.

Food and Agricultural Organization (1979): Manual food quality controlf or microbiological analysis.

Hussain and Kartela Y.Y. (1989), Traditional Hausa Plants used by the Hausa Tribe of Kano State of Nigeria. Int. J. Crude Drug Res. 27 (4): 211-216.

Junju H. (1990). African Traditional Medicine: A case study of Hausa Medicinal Plants and therapy. Gaskiya Coorporation Zaria, Kaduna Nigeria PP 20 - 137.

Mukhtar, M.D. and Okafor, A.c. (2002). Bioactive evaluation of ethanolic extracts of leaf and stem bark of Guiera Senegalensis. The Nig. J. research and Production 1 (I): 114-121.

Mukhtar et al (2001); In Shamsuddeen, U, Mukhtar, M.D; and Rakiya A; (2008): A survey on the microbiological quality of traditional medicine herbs concoctions vended in Kano, Nigeria. Journal of Medicinal and Pharmaceutical sciences, 4 (1).

Shamsuddeen, U, Mukhtar, M.D; and Rakiya A; (2008): A survey on the microbiological quality of traditional medicine herbs concoctions vended in Kano, Nigeria. Journal of Medicinal and Pharmaceutical sciences, volume 4, number 1, 2008. ISSN 1597 8036
Shariff Z.U. (2001). Modern herbal therapy for common oilments Natural Pharmacy series Vol. 1 Spectrum books Limited, Ibadan, Nigeria PP $1-84$.

Sri Lanka Ayurvedic drug Coorporation SLADC 1969 2009), www.ayurvedic Corporation. LK.

Sofowora: In Adeleye I.A, Okogi G, Ojo E.O (2010): Microbial contamination of herbal preparation in Lagos, Nigeria (p.296 - 297). E-mail: adeyemi21@yahoo.com Journal of Health Population and Nutrition.

Ugwunebo (2002); Herbal Preparations: National Agency for Food and Drug Administration and control (NAFDAC) consumer safety bulletin vol. 1 No.2 